\title{
The Italian Plum Rootstock Trial: Results for Sicilian Environmental Conditions
}

M. Monte, F.M. Impallari, G. Sala and F. Sottile

Dipartimento di Colture Arboree

Università di Palermo

Viale delle Scienze, $11-90128$

Italy

\author{
A. De Michele \\ Dipartimento di Scienze Entomologiche, \\ Fitopatologiche, Microbiologiche e \\ Zootecniche \\ Università di Palermo \\ Viale delle Scienze, 11 - 90128 \\ Italy
}

Keywords: development, tree, yield, fruit, Prunus domestica, Prunus salicina

\begin{abstract}
An increase of plum industry has been evident in Italy since the 1990s. This growth was in both area planted and production and it has been especially evident in the South of Italy, where the environmental conditions favor the development of plum orchards, particularly those adopting Japanese cultivars. The Myrobalan seedling was the main rootstock historically used in the south of the country for plum orchards, on account of its strong vigor, hardiness, longevity and adaptability to a wide range of soil types. The introduction of new scion cultivars and new rootstocks has stimulated new studies on the main technical aspects related to plum cultivation, to evaluate the wide number of rootstock genotypes which are today available for the plum species. The Italian Ministry of Agriculture has sponsored a National project which aims to evaluate the most recent rootstocks licensed and available for European and Japanese plum cultivars. A series of experimental orchards have been established in different regions representative of the main Italian plum growing areas. This paper reports on the vegetative and qualitative traits observed both for European and Japanese plum cultivars, respectively, 'Stanley' and 'Shiro', grafted onto five rootstocks.
\end{abstract}

\section{INTRODUCTION}

For at least the last 30 years the plum industry in Italy has been based on the cultivation of indigenous germplasm cultivars/varieties. In fact, there is a wide range of plum germplasm concentrated particularly in the south of the country; this scion germplasm is characterized by some interesting fruit traits - aroma, taste, flavor - which although partially linked to the cultivation areas, are thought to present considerable qualitative and productive potential. For this reason, considering the importance of this germplasm, interest has been expressed in these local cultivars, prompting some research studies.

Since the 1990s new cultivars have been introduced, and this has lead to the development of a plum industry mainly based on the cultivation of Japanese cultivars (Sansavini et al., 1996). During the same period, new rootstocks were introduced; these should be less variable in terms of vegetative growth and production than the diffused plum seedling and seedling-raised 'Myrobalan' used as traditional rootstocks.

In just a few years clonal 'Myrobalan 29C' has been rapidly adopted becoming the chosen rootstock in almost the $80 \%$ of the new plum plantings. The increase of interest on this facet of plum cultivation inspired the Italian Ministry of Agriculture to sponsor a National rootstock evaluation project (Mezzetti and Sottile, 2007). This aims to evaluate the most recent rootstocks, which are licensed and available for use with European and Japanese plum cultivars, by adopting a national network of experimental orchards. Actually, the recent advances in rootstock breeding and licensing appear very limited and few new genotypes have been licensed specifically for plum (Nicotra and Moser, 1997).

Proc. $9^{\text {th }}$ IS on Plum \& Prune Genetics, 


\section{MATERIALS AND METHODS}

The orchard was planted in 2001 at Collesano (PA) in a fertile and well-drained soil by using one-year-old grafted plants of 'Shiro' Japanese plum cultivar and 'Stanley' European plum cultivar. To warranty the pollen availability for the self-incompatible Japanese 'Shiro', in the orchard some trees of 'Sorriso di Primavera' were also opportunely displaced as a pollinator.

The cultivars 'Stanley' and 'Shiro', although very old, were chosen because they are very representative and widely distributed in the production areas in Italy. 'Stanley' is grown for its dual function as a plum for both for fresh market and for canning.

The experimental location in Sicily is characterized as a rather dry area (annual rainfall average $500 \mathrm{~mm}$ ), with very hot and dry summers and warm winters. The average maximum temperature is $24^{\circ} \mathrm{C}$ and the minimum is $14^{\circ} \mathrm{C}$.

Rootstocks adopted for the experimental design were the following: 'Myrobalan 29C' (Prunus cerasifera), 'MrS2/5' (Prunus cerasifera), 'GF677' (Prunus amygdalus $\times$ Prunus persica), 'Penta '(Prunus domestica) and 'Tetra' (Prunus domestica).

The trees were planted on the square, $4.5 \mathrm{~m}$ within and between the rows and trained to a regular vase habit with $4-5$ branches. The orchard is periodically cultivated, irrigated by a micro-sprinkler system from the end of May to the first of September. The experimental design is a complete randomized system with 15 trees for each grafting combination.

The parameters evaluated within this National project focus on both the vegetative and the fruit quantitative/qualitative traits. To record the vegetative traits and the cropping efficiency tree height was measured; the summer and winter pruning wood weight was recorded; the trunk circumference was measured $10 \mathrm{~cm}$ above the graft union every year starting at the planting time and used to calculate the trunk cross-sectional area - TCSA $\left(\mathrm{cm}^{2}\right)$. As a result, the cropping efficiency was calculated by the ratio of the production (yield in $\mathrm{kg}$ ) and the trunk cross-sectional area $\left(\mathrm{cm}^{2}\right)$. The canopy size was measured by recording the height and the N-S and W-E width; the canopy projection area on the soil, and therefore, the tree total yield/plant. Furthermore, considering the real occupancy of the tree on the soil by the canopy projection, the cropping efficiency was also calculated as the ratio of yield $(\mathrm{kg})$ to the area effectively occupied by the plant $\left(\mathrm{m}^{2}\right)$.

For the measurements of fruit qualitative traits, at harvest a sample of 30 fruits randomly picked was used to record fruit weight, firmness, soluble solids and titratable acidity. An Analysis of Variance was performed and the differences were compared by using the Tukey test at $\mathrm{P} \leq 0.05$.

\section{RESULTS AND DISCUSSION}

\section{Vegetative Traits}

1. European Plum (P. domestica). The vegetative traits measurements showed that on average that trees of 'Stanley' grafted onto 'GF 677' were significantly the most vigorous (Table 1). The values for weight of pruning wood, trunk cross-sectional area - TCSA $\left(\mathrm{cm}^{2}\right)$ and canopy projection, give estimates of the relative vigour of trees on 'GF 677'. In contrast trees on 'Penta' exhibited low vigour; while the results obtained with 'MrS $2 / 5$ 'and 'Tetra' were intermediate with respect to the others.

The data concerning cropping efficiency are for the year 2006 both for Japanese and European plum. The cropping efficiency is only reported for 2006 because in 2007 the growing season was not favourable to production and all the data were not considered appropriate. Also in this case, the highest cropping efficiency was shown by trees grafted onto 'GF 677' while the lowest was shown by trees on 'Penta', the intermediary performance was recorded by 'Tetra' and 'MrS 2/5'.

The same efficiency parameter obtained using canopy projection, confirmed the highest value for trees on 'GF 677' and the lowest for trees on 'Penta' (Table 2).

2. Japanese Plum. As with the European plums the data on Japanese plum confirmed the higher vigour of ' $\mathrm{GF} 677$ ' in terms of tree development, wood pruning, trunk cross- 
sectional area $\left(\mathrm{cm}^{2}\right)$ and canopy projection (Table 3$)$. Comparing the five rootstocks, 'Penta' showed the lowest vigour, 'MrS $2 / 5$ ' and 'Tetra' were intermediate.

In terms of cropping efficiency, 'GF 677' and 'Myrobalan 29C' induced more efficient production and once and again 'Penta' showed the lowest (Table 4).

Comparing the two types of plums, the Japanese and the European, the canopy projections shown in Figures 1 and 2 indicate that trees on the former were more vigorous than those on the latter type.

\section{Qualitative Traits}

The European cultivar 'Stanley' grafted onto 'GF677' produced fruits with the highest values of firmness but the lowest in terms of soluble solids content; it is possible that this effect is attributable to the slightly later ripening time induced, although higher crop loads may also lower individual fruit soluble solids. With 'Myrobalan 29C' the fruit quality showed high soluble solids values, while with the low vigour rootstocks, the fruit size and soluble solids contents were also good (Table 5).

For the Japanese plum cultivar 'Shiro', the trees grafted onto 'MrS 2/5' appeared to have fruits exhibiting the lowest firmness (effect not, however, statistically significant). It is probable that this is associated with the earliest ripening time induced by this lowvigour rootstock. 'Myrobalan 29C' induced fruits of large size (Table 6).

\section{CONCLUSIONS}

All the data obtained showed the high vigour potential of trees on 'GF 677' confirming previous observations. It will be necessary to delay any final judgments on these rootstocks until the trees are somewhat older. However the results concerning canopy projection show that the spacing's adopted within the National evaluation project and assigned to the trees, seems excessive and that trees could be planted closer together in these environmental conditions.

The qualitative traits confirm the known good performance in Sicily of both types of plum grafted onto 'Myrobalan 29 C' and trees on 'GF 677'also showed early promise. The lower vigour rootstocks affected ripening times and soluble solids contents, gave higher values of firmness and soluble solids content than the more vigorous rootstocks 'GF 677' and 'Myrobalan 29C'. This may be partly attributable to lower crop loading on the trees and differences in ripening times. This needs further investigation.

\section{Literature Cited}

Nicotra, A. and Moser, L. 1997. Two new plum rootstocks for peach and nectarines: Penta and Tetra. Acta Hort. 451:267-271.

Mezzetti, B. and Sottile, F. 2004. MiPAF Targeted Project for Evaluation of European and Cino-Japanese Plum Rootstocks in Italy: Results of Six Years of Observations. Acta Hort. 734:149-156.

Sansavini, S., Lugli, S., Martelli, S. and Grandi, M. 1996. Nuove varietà e portinnesti di susino: si allarga il ventaglio delle scelte - Riv. di Frutticoltura 9:23-32.

Sottile, F., Nencetti, V., Monte, M. and Bellini, E. 2002. Liste varietali: susino (cinogiapponese ed europeo). Supplemento a Inf. Agr. 23:76-82. 


\section{$\underline{\text { Tables }}$}

Table 1. Vegetative traits in European plum tree cultivar 'Stanley' grafted onto five genetically different rootstocks.

\begin{tabular}{lcccc}
\hline & $\begin{array}{c}\text { Tree height } \\
(\mathrm{cm})\end{array}$ & $\begin{array}{c}\text { Pruning wood weight } \\
(\mathrm{kg})\end{array}$ & $\begin{array}{c}\text { TCSA } \\
\left(\mathrm{cm}^{2}\right)\end{array}$ & $\begin{array}{c}\text { Canopy } \\
\text { projection } \\
\left(\mathrm{m}^{2}\right)\end{array}$ \\
\hline Myrobalan 29 C & 275 n.s. & 2,3 n.s. & $38,9 \mathrm{~b}$ & $5,3 \mathrm{~b}$ \\
GF 677 & 310 & 7,4 & $73,4 \mathrm{a}$ & $8,1 \mathrm{a}$ \\
MrS 2/5 & 306 & 1,6 & $39,4 \mathrm{~b}$ & $3,6 \mathrm{c}$ \\
Penta & 304 & 0,9 & $27,4 \mathrm{c}$ & $2,9 \mathrm{c}$ \\
Tetra & 352 & 1,3 & $39,6 \mathrm{~b}$ & $5,2 \mathrm{~b}$ \\
\hline
\end{tabular}

Different letters on the same column denote statistical differences per $\mathrm{P}<0.05$.

ns $=$ not significant.

Table 2. Cropping of European plum tree cultivar 'Stanley' grafted onto five genetically different rootstocks.

\begin{tabular}{lcc}
\hline & $\begin{array}{r}\text { Cropping by TCSA } \\
\left(\mathrm{kg} / \mathrm{cm}^{2}\right)\end{array}$ & $\begin{array}{r}\text { Cropping by canopy projection } \\
\left(\mathrm{kg} / \mathrm{m}^{2}\right)\end{array}$ \\
\hline Myrobalan 29 C & $0,2 \mathrm{n} . \mathrm{s}$. & $1,5 \mathrm{n} . \mathrm{s}$ \\
GF 677 & 0,2 & 1,6 \\
MrS 2/5 & 0,1 & 1,5 \\
Penta & 0,1 & 1,1 \\
Tetra & 0,1 & 0,9 \\
\hline
\end{tabular}

Different letters on the same column denote statistical differences per $\mathrm{P}<0.05$.

ns $=$ not significant.

Table 3. Vegetative traits in Japanese plum tree cultivar 'Shiro' grafted onto five genetically different rootstocks

\begin{tabular}{lcccc}
\hline & $\begin{array}{c}\text { Tree height } \\
(\mathrm{cm})\end{array}$ & $\begin{array}{c}\text { Pruning wood weight } \\
(\mathrm{kg})\end{array}$ & $\begin{array}{c}\text { TCSA } \\
\left(\mathrm{cm}^{2}\right)\end{array}$ & $\begin{array}{c}\text { Canopy projection } \\
\left(\mathrm{m}^{2}\right)\end{array}$ \\
\hline Myrobalan 29 C & 274 n.s. & 3,9 n.s. & $97,7 \mathrm{ab}$ & $7,6 \mathrm{n} . \mathrm{s}$ \\
GF 677 & 328 & 11,4 & $127,4 \mathrm{a}$ & 11,1 \\
MrS 2/5 & 232 & 1,2 & $54,7 \mathrm{~b}$ & 5,7 \\
Penta & 197 & 0,3 & $23,0 \mathrm{c}$ & 3,6 \\
Tetra & 238 & 1,1 & $36,3 \mathrm{bc}$ & 5,7 \\
\hline
\end{tabular}

Different letters on the same column denote statistical differences per $\mathrm{P}<0.05$.

ns $=$ not significant. 
Table 4. Cropping of Japanese plum tree cultivar 'Shiro' grafted onto five genetically different rootstocks.

\begin{tabular}{lcc}
\hline & $\begin{array}{r}\text { Cropping by TCSA } \\
\left(\mathrm{kg} / \mathrm{cm}^{2}\right)\end{array}$ & $\begin{array}{c}\text { Cropping by canopy projection } \\
\left(\mathrm{kg} / \mathrm{m}^{2}\right)\end{array}$ \\
\hline Myrobalan 29 C & $0,15 \mathrm{ab}$ & $2,0 \mathrm{n} . \mathrm{s}$ \\
GF 677 & $0,19 \mathrm{a}$ & 2,2 \\
MrS 2/5 & $0,12 \mathrm{ab}$ & 1,1 \\
Penta & $0,09 \mathrm{~b}$ & 0,6 \\
Tetra & $0,12 \mathrm{ab}$ & 0,8 \\
\hline
\end{tabular}

Different letters on the same column denote statistical differences per $\mathrm{P}<0.05$.

ns=not significant.

Table 5. Qualitative traits in European plum tree cultivar 'Stanley' grafted onto five genetically different rootstocks.

\begin{tabular}{lccccc}
\hline & $\begin{array}{c}\text { Fruit } \\
\text { weight } \\
(\mathrm{g})\end{array}$ & $\begin{array}{c}\text { Firmness } \\
\left(\mathrm{kg} / \mathrm{cm}^{2}\right)\end{array}$ & $\begin{array}{c}\text { Titratable } \\
\text { acidity } \\
(\mathrm{mg} / \mathrm{L})\end{array}$ & $\begin{array}{c}\text { Soluble } \\
\text { solids } \\
\left({ }^{\circ} \text { Brix }\right)\end{array}$ & SSC/TA \\
\hline Myrobalan 29 C & $36,6 \mathrm{~b}$ & 2,4 n.s. & $0,5 \mathrm{n} . \mathrm{s}$. & $16,1 \mathrm{a}$ & $30,5 \mathrm{a}$ \\
GF 677 & $42,2 \mathrm{a}$ & 2,5 & 0,5 & $12,7 \mathrm{~b}$ & $23,9 \mathrm{~b}$ \\
MrS 2/5 & $34,3 \mathrm{c}$ & 2,5 & 0,5 & $15,9 \mathrm{~b}$ & $29,8 \mathrm{~b}$ \\
Penta & $37,9 \mathrm{~b}$ & 2,4 & 0,6 & $15,2 \mathrm{bc}$ & $27,2 \mathrm{ab}$ \\
Tetra & $40,2 \mathrm{a}$ & 2,3 & 0,5 & $14,4 \mathrm{c}$ & $28,2 \mathrm{~b}$ \\
\hline
\end{tabular}

Different letters on the same column denote statistical differences per $\mathrm{P}<0.05$.

ns $=$ not significant.

Table 6. Qualitative traits in Japanese plum tree cultivar 'Shiro' grafted onto five genetically different rootstocks.

\begin{tabular}{lccccc}
\hline & $\begin{array}{c}\text { Fruit } \\
\text { weight } \\
(\mathrm{g})\end{array}$ & $\begin{array}{c}\text { Firmness } \\
\left(\mathrm{kg} / \mathrm{cm}^{2}\right)\end{array}$ & $\begin{array}{c}\text { Titratable } \\
\text { acidity } \\
(\mathrm{mg} / \mathrm{L})\end{array}$ & $\begin{array}{c}\text { Soluble } \\
\text { solids } \\
\left({ }^{\circ} \text { Brix }\right)\end{array}$ & SSC/TA \\
\hline Myrobalan 29 C & $36,5 \mathrm{a}$ & 1,4 n.s. & 1,2 n.s. & 15,0 n.s. & $12,1 \mathrm{a}$ \\
GF 677 & $48,4 \mathrm{~b}$ & 1,5 & 1,7 & 14,9 & $8,7 \mathrm{~b}$ \\
MrS 2/5 & $31,0 \mathrm{~b}$ & 1,2 & 1,0 & 15,7 & $15,7 \mathrm{ab}$ \\
Penta & $28,7 \mathrm{~b}$ & 1,4 & 1,0 & 15,4 & $14,8 \mathrm{ab}$ \\
Tetra & $30,5 \mathrm{~b}$ & 1,3 & 1,1 & 15,4 & $14,3 \mathrm{~b}$ \\
\hline
\end{tabular}

Different letters on the same column denote statistical differences per $\mathrm{P}<0.05$.

ns $=$ not significant. 


\section{Figures}

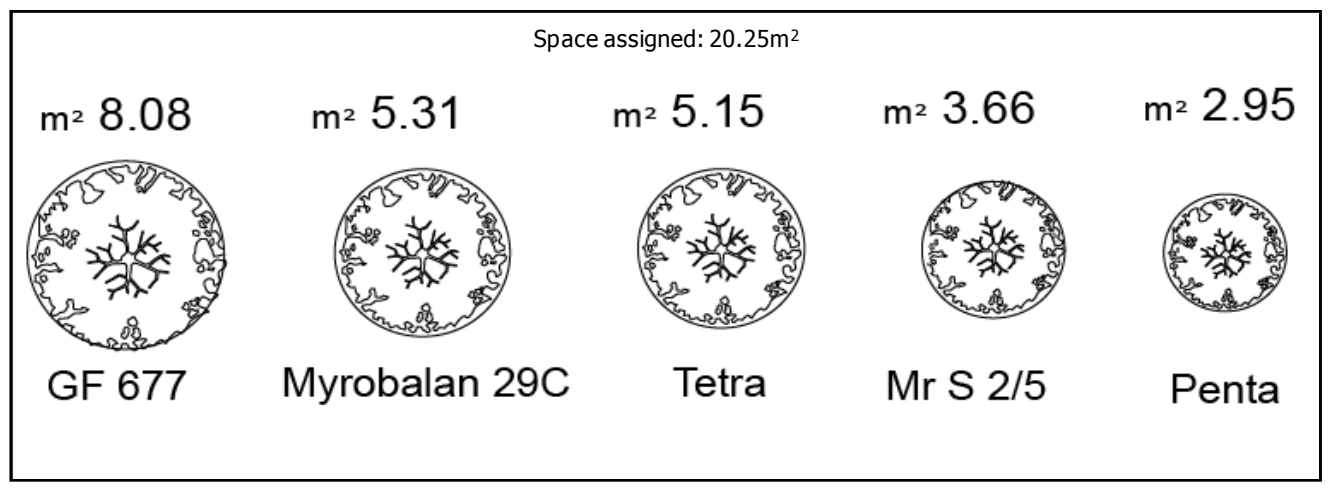

Fig. 1. Canopy projection on the soil of European plum tree cultivar 'Stanley' grafted onto five genetically different rootstocks.

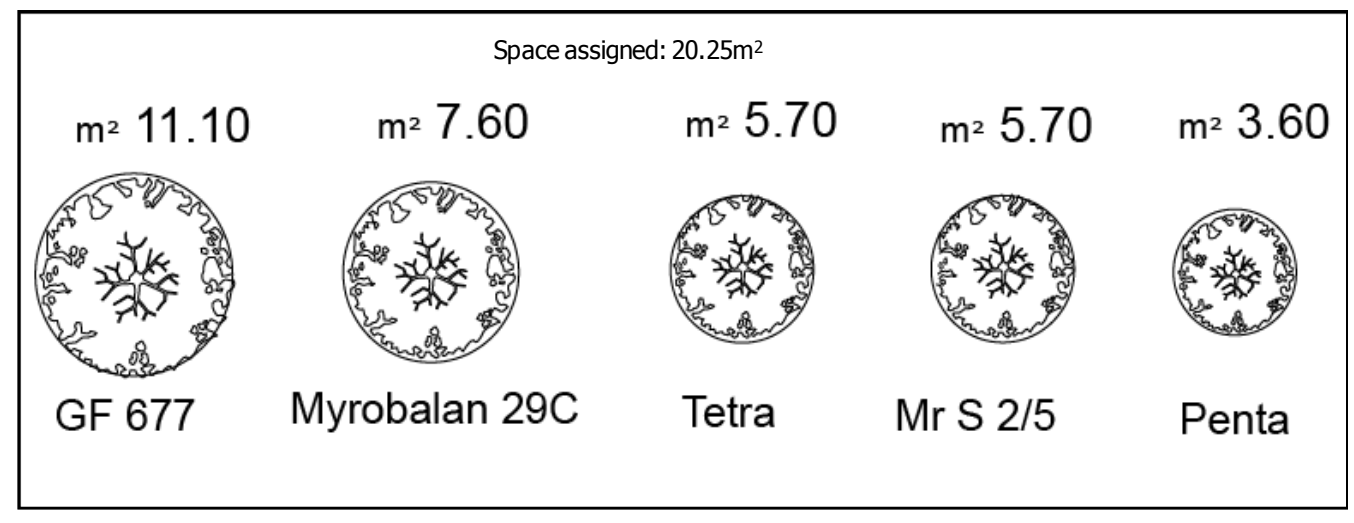

Fig. 2. Canopy projection on the soil of Japanese plum tree cultivar 'Shiro' grafted onto five genetically different rootstocks. 